\title{
41HSS74, The Coleman Farm Site on Starkey Creek
}

Timothy K. Perttula

Heritage Research Center, Stephen F. Austin State University

Bo Nelson

Heritage Research Center, Stephen F. Austin State University

Follow this and additional works at: https://scholarworks.sfasu.edu/ita

Part of the American Material Culture Commons, Archaeological Anthropology Commons, Environmental Studies Commons, Other American Studies Commons, Other Arts and Humanities Commons, Other History of Art, Architecture, and Archaeology Commons, and the United States History Commons

Tell us how this article helped you.

This Article is brought to you for free and open access by the Center for Regional Heritage Research at SFA ScholarWorks. It has been accepted for inclusion in Index of Texas Archaeology: Open Access Gray Literature from the Lone Star State by an authorized editor of SFA ScholarWorks. For more information, please contact cdsscholarworks@sfasu.edu. 


\section{HSS74, The Coleman Farm Site on Starkey Creek}

Creative Commons License

(c) (i) (8)

This work is licensed under a Creative Commons Attribution-NonCommercial 4.0 International License 


\title{
41HS574, The Coleman Farm Site on Starkey Creek
}

\author{
Timothy K. Perttula and Bo Nelson
}

\section{Introduction}

Recent archaeological research on the Middle Caddoan period in Northeast Texas has made it abundantly clear that Middle Caddoan archaeological sites are much more common in the region than previously thought (e.g., Middlebrook and Perttula 1997). Furthermore, with additional archaeological investigations, some radiocarbon dates, and a different perspectives on the regional archaeological record, a number of sites in the Sabine River drainage that used to be considered of Late Caddoan age (cf. Perttula et al. 1986) are now more properly seen to be part of an intensive Middle Caddoan settlement of much of the basin (Perttula and Cruse 1997). Truly, a broader and more complete view of the important Middle Caddoan period (ca. A.D. 1200-1400) in Northeast Texas looms before us.

With the understanding of the Middle Caddoan period increasing anew through field investigations, as well as the synthetic efforts of the East Texas Caddoan Research Group, and the implications of new archaeological findings (such as the Oak Hill Village excavation) a further motivation for new archaeological research, documenting other Middle Caddoan sites remains important. That is the goal of this paper, namely to document an assemblage of lithic and ceramic artifacts from a late Middle Caddoan period component at the Coleman Farm site (41HS574) in Harrison County, Texas. The archaeological materials reported on here are from a surface collection made by Marshall Macintosh at the site in late 1994.

\section{Site Setting}

The Coleman Farm site is located on a ridge or low terrace immediately overlooking Starkey Creek, a permanent stream tributary to Potters Creek. It is $250 \times 50 \mathrm{~m}$ in size, covering about 3.1 acres. From its confluence with Starkey Creek, Potters Creek, one of the main south-flowing streams of the Sabine River in the middle Sabine River basin, flows south about 3-4 km to the Sabine River floodplain. The elevation of the ridge is 265275 feet above mean sea level.

A number of important archaeological sites are known on Potters and Starkey creeks in the vicinity of the Coleman Farm site. A short distance to the west is the Gus Jones or Pine Tree Mound site (41HS15), likely a Middle Caddoan period construction, while the Early Ceramic period Resch site (41HS16) lies $2.5 \mathrm{~km}$ to the south (Webb et al. 1969). The Susie Slade (41HS13) site, a large Historic Caddoan Kinsloe phase cemetery and habitation area (Jones 1968), is on a floodplain knoll along Potter's Creek, not far to the southwest of the Resch site

\section{Lithic Tools and Debris}

A single broken Perdiz arrowpoint has been documented from the Coleman Farm site. Perdiz arrow points are present in Caddo sites in the area from about the latter portion of the Middle Caddoan period (ca. A.D. 1300) to about A.D. 1500, the earlier part of the Late Caddoan period. 
The arrowpoint is made of a local tannish-colored chert, and a small remnant of gravel or stream-rolled cortex remains on the blade. The Perdiz is manufactured on a complete flake, and the blade is retouched for finishing only on the dorsal surface; on the ventral surface, retouch is present only on the stem. The Perdiz has been broken by a transverse blade fracture, probably during manufacture. Size measurements include a blade width of 13.2 $\mathrm{mm}$; a neck width of $4.6 \mathrm{~mm}$; a $5.4 \mathrm{~mm}$ stem length; and the arrowpoint is $3.4 \mathrm{~mm}$ thick.

The lithic debris includes 159 flakes or flake fragments and seven cores. All of the cores and $93 \%$ of the lithic debris are on local raw materials, including petrified wood, quartzite, red, tan, and yellow chert, and chalcedony. The few pieces of non-local lithic debris are of a gray to creamy white novaculite $(n=12)$ and a dark, chocolate brown chert $(n=1)$. This particular piece of chert is probably derived from the Edwards Formation (cf. Frederick and Ringstaff 1994).

Ten of the 12 pieces of novaculite lithic debris are small non-cortical or pieces, probably retouching or finishing flakes, while the other two are small non-cortical biface thinning flakes. These are the only biface thinning flakes in the Coleman Farm lithic debris sample. The probable Edwards Chert flake is also a non-cortical piece, perhaps from the resharpening of a completed tool.

The cores include two tested cobbles, a single-platform core, one discoidal core, and three multiple platform cores. Because of the absence of bifacial preforms and discarded and broken bifaces, as well as the small size of the cores, and the evidence for flake removals on the cores, the reduction of pebbles and cobbles at Coleman Farm appears to have been designed to obtain usable flakes, rather than the shaping of tools directly from thick cores. Such reduction methods are consistent with a Caddoan lithic technology (cf. Shafer 1973; Girard 1995).

The tested cobbles are on a red chert and a coarse-grained quartzite. Each had one flake removal. The cobbles ranged from 27-34 mm in length, 22-25 m in width, and 13-14 mm in thickness. The single platform core, of local red chert, had 5+ flake removals before it was discarded. It was $34 \times 20 \times 14$ mm in length, width, and thickness.

An interesting red chert discoidal core is in the Coleman Farm collection. Two horizontal flake removals extend across the prepared platform of the piece to facilitate working of the small pebble ( $45 \times 34 \times 23 \mathrm{~mm}$ in length, width, and thickness) creating a disc-shaped core with a prepared working platform that had five more flake removals. The three multiple platform cores had flakes removed from several platforms, and then they were apparently discarded after no other usable flakes could be obtained. These cores are of red $(n=2)$ and yellow $(\mathrm{n}=1)$, and ranged from $31-45 \mathrm{~mm}$ in length, $24-35 \mathrm{~mm}$ in width, and $14-24 \mathrm{~mm}$ in thickness.

More than $43 \%$ of the lithic debris on local lithic raw materials are cortical pieces, suggesting the manufacture of lithic tools on site from local gravels. Based on the small size and character of the cores, the knappable raw materials in the gravels are probably pebble-sized or smaller pieces with a stream-rolled cortex rind. The presence of the discshaped core suggests special efforts were made to extend the use of the small pieces of raw material, as does a single chert bipolar flake in the collection.

The lithic raw material represented in the lithic debris includes chalcedony $(n=2)$, petrified wood $(n=37)$, quartzite $(n=26)$, and chert $(n=81)$. Both of the chalcedony pieces are complete non-cortical flakes, while cortical pieces are well represented among the petrified wood (49 percent), quartzite ( 23 percent), and chert (51 percent) raw materials. Further evidence of the small size of the raw materials available to the inhabitants of the Coleman 
Farm site is the size of the complete flakes in the chert lithic debris: (a) the complete cortical pieces range in length from $15-28 \mathrm{~mm}$, width from $13-25 \mathrm{~mm}$, and from $2-4 \mathrm{~mm}$ in thickness; and (b) the range in non-cortical flake sizes is $18-25 \mathrm{~mm}$ in length, $9-16 \mathrm{~mm}$ in width, and $2.5-4 \mathrm{~mm}$ in thickness. The chert bipolar flake is $29 \times 23 \times 6 \mathrm{~mm}$ in length, width, and thickness.

\section{Ceramics}

There are 111 ceramic sherds in the Coleman Farm collection, 49 plain body sherds, one base sherd, two plain rim sherds, and 59 decorated rim and body sherds. Included in the decorated sherds are five rims. Grog (crushed sherds), burned bone, and grit inclusions are the primary tempering materials in the sherd assemblage, with grog the most common aplastic ( 49 percent), followed by bone ( 27 percent), grog and bone ( 15 percent), and bone and grit ( 8 percent). About 25 percent of the sherds have a noticeable sandy paste, and these have been tempered with finely-crushed grog or burned bone. The other sherds are from vessels with coarser temper inclusions and a clay paste.

The plain rims have direct and folded (exterior) rim profiles with rounded lips. They have not been smoothed or burnished, and show no sooting or smudging from use over a fire; they are probably from two different bowls, based on rim thickness measurements of 3.6 $\mathrm{mm}$ thick and $7.1 \mathrm{~mm}$ thick (the folded rim).

Most of the plain body sherds have smoothed interior and exterior surfaces (65 percent), two (4 percent) have exterior burnishing, and one has a red slip on its interior and exterior surfaces. The latter three sherds are from thin-walled $(5.6 \pm 0.3 \mathrm{~mm})$ bowls tempered with finely-crushed bone. The smoothed and unsmoothed body sherds are from slightly thicker vessels (mean thickness of $6.75 \pm 1.45 \mathrm{~mm}$ ), probably representing a combination of bowls and jars. The single flat disc-shaped base sherd is $12.5 \mathrm{~mm}$ thick.

There is an interesting assortment of decorated Caddo sherds from the Coleman Farm site. By far the most common decorative element among the 59 sherds is parallel (probably vertically oriented) brushing on the body of jars, which comprises 64 percent of the decorated sherds. Sherds where brushing appears to be the primary decorative element amount to 76 percent of the decorated sherds. Besides the parallel brushed sherds, this includes two other sherds with brushing marks that are more haphazardly oriented, the marks overlapping each other in no discernible manner. One small rim sherd has horizontal brushing, while another has horizontal brushing on the rim and vertically-placed rows of punctations beginning at the lip and apparently extending down the rim. Four body sherds have brushing marks divided by clay appliqued strips. The latter are probably sherds from Pease Brushed-Incised jars.

Including the punctated and brushed rim mentioned above, there are six punctated rim and body sherds in the Coleman Farm collection. These all appear to be from jars with vertically-placed rows of punctations on the rim as well as body punctations. One of the vertically-punctated rims has a burnished exterior surface, and the rim is peaked, while on another the row of punctations begins slightly below the lip. Punctations on the body sherds include cane-impressed, tool-impressed, and fingernail-impressed decorative elements.

The few engraved sherds ( 8.4 percent of the decorated sherds) are represented by broad horizontal elements, probably a series of horizontal lines on the rim of bowls and carinated bowls. One sherd has a small pendant triangle motif. 
Incised sherds comprise only 3.4 percent of the decorated sherds from the site. The decorative elements on the two body sherds are parallel and parallel and perpendicular incised lines. The orientation of the motifs are uncertain because the sherds are small in size, but cross-hatched, diagonal, and herringbone incised motifs are common on Middle and Late Caddoan jars and bowls in the middle Sabine River basin.

Besides the brushed-appliqued sherds described above, there is a single sherd in the collection with an appliqued node. Such nodes are usually found in sets of four on the rim of cooking jars.

Looking at the decorated ceramic sherds from the Coleman Farm site as a whole, with the high frequency of brushed sherds, some with rim punctations or appliqued strips, rows of rim punctations, horizontal engraving on the rim, and low amounts of incised sherds, the site appears to date to the latter part of the Middle Caddoan period (ca. A.D. 1300-1400). An analysis of changes in ceramic decorative elements in Caddoan sites dating from ca. A.D. 1100-1400+ from the middle Sabine River basin (mainly southern Harrison County and northern Panola and Rusk counties) suggests that the latest Middle Caddoan period sites have abundant brushed pottery (75-83 percent of the decorated ceramics)--as does the Coleman Farm site--with much smaller amounts of punctated (6-9 percent) and engraved (4-10 percent) vessel sherds; appliqued sherds, although uncommon, also seem characteristic of this period (Perttula 1997). Eight percent of the decorated sherds at Coleman Farm have engraved motifs and another 10.2 percent of the sherds are punctated. Caddoan sites at the earlier end of the ceramic sequence have little to no brushed pottery (< 20 percent), with incised, punctated, and punctated-incised decorative elements dominating the ceramic assemblages (i.e., at the Gray's Pasture site [41HS524], 79 percent of the decorated sherds have incised, punctated, and punctated-incised decorative elements). At Coleman Farm, only 13.6 percent of the decorated sherds are from vessels with incised, punctated, or punctated-incised decorations.

\section{Daub}

The Coleman Farm site collection includes two pieces of daub with stick impressions. While they are not much to go on, they do suggest that a Caddoan structure or structures stood on the site.

\section{Bone}

A few small pieces of burned and unidentifiable animal bone $(n=3)$ and two pieces of human bone (skull fragments) are in the Coleman Farm collection. The preservation of animal bone indicates that preserved features and/or midden deposits are present, while the human bone is stark evidence for the existence of disturbed Caddoan burials at the site.

The burials and their accompanying grave goods are, of course, what made the Coleman site attractive to looters and pothunters in the first place, bringing it to the attention of Marshall Macintosh. Several burials are reported to have been looted from the site by a well-known pothunter, and Natchitoches Engraved vessels are reported to have been found by the looter. Based on the historic (i.e., post-A.D. 1685) age of Natchitoches Engraved vessels in Caddo sites in Northeast Texas (Perttula 1992), and the occurrence of historic Kinsloe phase Caddo burials on Potter's Creek and the Sabine River not far from Coleman Farm, it is likely that an historic Kinsloe phase component with burials is present at the site. 


\section{Summary}

The analysis of the lithic and ceramic artifacts from the Coleman Farm site suggests it is primarily a Middle Caddoan period habitation site. The decorated ceramics from the site are quite consistent with other contemporaneous Middle Caddoan period sites in southern Harrison, northern Panola, and northern Rusk counties (see Perttula and Cruse 1997), and it appears to be the case from previous investigations in the area that there is extensive and lengthy settlement of Middle Caddoan horticulturists in the Potters Creek and Starkey Creek drainages.

If the information concerning the pothunter activities at the Coleman Farm site is accurate, and the presence of a small amount of human remains in the collections is certainly suggestive, then in Historic Caddoan times (probably sometime in the 18th century), the Coleman Farm site was also used as a burial ground by a Caddo group living in the Potters Creek drainage basin. Several other Historic Caddoan burial sites and settlements are known in the Potters Creek area.

\section{Acknowledgments}

We appreciate the willingness of Marshall Macintosh to let us study the archaeological materials from the Coleman Farm site.

\section{References}

Frederick, C. D. and C. Ringstaff

1994 Lithic Resources at Fort Hood: Further Investigations. In Archeological Investigations on 571 Prehistoric Sites at Fort Hood, Bell and Coryell Counties, Texas, edited by W. N. Trierweiler, pp. 125-181. Archeological Resource Management Series, Research Report No. 31. United States Army Fort Hood, Fort Hood, Texas.

Girard, J. S.

1995 The Chipped Stone Collection: Technological, Functional, and Typological Analyses. In The Deshazo Site, Nacogdoches County, Texas, Volume 2: Artifacts of Native Manufacture, edited by D. A. Story, pp. 33-156. Studies in Archeology 21. Texas Archeological Research Laboratory, The University of Texas at Austin.

Jones, B. C.

1968 The Kinsloe Focus: A Study of Seven Historic Caddo Sites in Northeast Texas. Master's thesis, Department of Anthropology, University of Oklahoma, Norman.

Middlebrook, T. and T. K. Perttula

1997 The Middle Caddoan Period in East Texas: A Summary of the Findings of the East Texas Caddoan Research Group. Journal of Northeast Texas Archaeology No. 9:18.

Perttula, T. K.

1992 "The Caddo Nation": Archaeological and Ethnohistoric Perspectives. University of Texas Press, Austin. 
1997 The Caddoan Ceramics from the Gray's Pasture Site (41HS524). MS on file with the author.

Perttula, T. K. and J. B. Cruse

1997 The Caddoan Archaeology of the Sabine River Basin during the Middle Caddoan Period. Journal of Northeast Texas Archaeology No. 9:30-37.

Perttula, T. K., B. D. Skiles, M. B. Collins, M. C. Trachte, and F. Valdez, Jr.

1986 "This Everlasting Sand Bed": Cultural Resources Investigations at the Texas Big Sandy Project, Wood and Upshur Counties, Texas. Reports of Investigations No. 52. Prewitt and Associates, Inc., Austin.

Shafer, H. J.

1973 Lithic Technology at the George C. Davis Site, Cherokee County, Texas. Unpublished Ph.D. dissertation, Department of Anthropology, The University of Texas at Austin.

Webb, C. H., F. E. Murphey, W. G. Ellis, and H. R. Green

1969 The Resch Site, 41HS16, Harrison County, Texas. Bulletin of the Texas Archeological Society 40:3-106. 